\title{
Investigation of Thrust Force and Delamination during Drilling of C/PPS
}

Petr Masek ${ }^{1}$, Petr Kolar ${ }^{2}$, Pavel Zeman ${ }^{2}$, Martin Vrabec ${ }^{1}$

${ }^{1}$ Faculty of Manufacturing Technology - Department of Machining, Process Planning and Metrology, Czech Technical University in Prague, Technicka 4, 16607 Praha 6. Czech Republic. E-mail: p.masek@rcmt.cvut.cz

${ }^{2}$ Faculty of Manufacturing Technology - Research Centre of Manufacturing Technology, Czech Technical University in Prague, Horska 3, 12800 Praha 2. Czech Republic. E-mail: p.kolar@rcmt.cvut.cz

Drill bits used for machining of composite materials can have different geometries and it is difficult to choose suitable geometry for a specific type of composite. Unsuitable geometry of a drill bit leads to bad surface quality. The objective of this paper is to find the most suitable drill bit geometry for machining of the thermoplastic composite C/PPS in terms of surface quality and magnitude of thrust force under different cutting conditions. Three drill bits were chosen for experimental investigation. A significant influence of the point angle was identified. A gradually decreased point angle together with an increased rake angle of the cutting edge lead to better surface quality. In addition, investigation of the influence of cutting conditions on surface quality and cutting forces was performed. A considerable influence of feed was observed in comparison to cutting velocity. Information included in this paper can help to design more suitable technology for drilling of thermoplastic composites.

Keywords: FRTC drilling, Drilling tools, Delamination, Cutting forces

\section{Acknowledgement}

The presented results were achieved within the "Fibrechain" project. The project has received funding from the European Union's Seventh Framework Programme for research, technological development and demonstration under grant agreement no. 263385.

\section{References}

[1] PETERS, S. T. (1998). Handbook of Composites, p. 1120. Chapman and Hall, London.

[2] QUADRINI, F., SQUEO, E. A., TAGLIAFERRI, V. (2007 ). Machining of glass fiber reinforced polyamide, eXpress Polymer letters, Vol. 1, No.12. pp. 434 - 438. Rome.

[3] SHEIKH-AHMAD, J. Y. (2009). Machining of polymer composites, p. 320. Springer Science + Business Media, New York.

[4] VALÁŠEK, P., MÜLLER, M. (2012). Influence of bonded abrasive particles size on wear of polymeric particle composites based on waste. Manufacturing technology. Vol.12. No. 13. pp. 268-272.

[5] MÜLLER, M., VALÁŠEK, P. (2015). Abrasive wear effect on Polyethylene, Polyamide 6 and polymeric particle composites. Manufacturing technology. Vol.12. No. 12. pp. 55-59.

[6] HOCHENG, H., PUW, H. Y. (1992). On drilling characteristic of fiber-reinforced thermoset and thermoplastics, International Journal of Machining Tools and Manufacturing. pp. 583-592. UK.

[7] CHEN, W. (1997). Some experimental investigations in the drilling of carbon fiber-reinforced plastic (CFRP) composite laminates, International Journal of Machining Tools and Manufacturing. pp. 1097-1108. UK.

[8] LAUCHAD, F., PIQUET, R., COLlOMBET, F. (2001). Drilling of composite structures, Composite structures. Vol. 52. pp. 511-516.

[9] HOCHENG, H., PUW H. Y. (1993). Machinability of Fiber-Reinforced Thermoplastic in Drilling, Journal of Engineering Materials and Technology, Vol. 115, pp. 146-149.

[10] RAHME, P., LANDON, Y., LAUCHAD, F., R. PIQUET (2010). Analytical models of composite material drilling, Int. J. Adv. Manuf. Technol. Vol. 52, pp. 609-617.

[11] DAVIM, P. J. a REIS, P. (2003). Drilling carbon fiber reinforced plastics manufactured by autoclave experimental and statistical study, Materials and Design, Vol. 24, pp. 315-324.

[12] HEISEL, U. a PFEIFROTH, T. (2012). Influence of Point Angle on Drill Hole Quality and Machining Forces when Drilling CFRP, 5th CIRP Conference on High Performance Cutting 2012. pp. 488 - 493.

[13] KOLESNYK,V., KRYVORUCHKO, D., HATALA, M. (2015). The Effect of Cutting Temperature on Carbide Drilling Life in the Process of CFRP/Steel Stacks Drilling. Manufacturing technology. Vol.15. No. 3. pp. $357-362$. 
[14] ASTAKHOV, V. P. (2014). Drills: Science and Technology of Advanced Operations, CRC Press, Boca Raton.

[15] DAVIM, J. (2010). Machining composite materials. ISTE Ltd, Great Britain.

[16] SEDLACEK, J. (2010). Analysis of delamination in drilling of composite materials, MM SCIENCE (June). pp. 194-197.

\section{Paper number: M2016242}

Copyright (C) 2016. Published by Manufacturing Technology. All rights reserved. 